"Educational reforms and curriculum transformation in post-apartheid South Africa"

\begin{tabular}{|c|c|c|}
\hline AUTHORS & $\begin{array}{l}\text { Vusi Gumede } \\
\text { Mduduzi Biyase }\end{array}$ & \\
\hline ARTICLE INFO & \multicolumn{2}{|c|}{$\begin{array}{l}\text { Vusi Gumede and Mduduzi Biyase (2016). Educational reforms and curriculum } \\
\text { transformation in post-apartheid South Africa. Environmental Economics, } 7(2) \text {, } \\
69-76 \text {. doi:10.21511/ee.07(2).2016.7 }\end{array}$} \\
\hline DOI & \multicolumn{2}{|c|}{ http://dx.doi.org/10.21511/ee.07(2).2016.7 } \\
\hline RELEASED ON & \multicolumn{2}{|l|}{ Friday, 03 June 2016} \\
\hline JOURNAL & \multicolumn{2}{|l|}{ "Environmental Economics" } \\
\hline FOUNDER & \multicolumn{2}{|c|}{ LLC "Consulting Publishing Company "Business Perspectives" } \\
\hline & & $\begin{array}{l}=-= \\
= \pm=\end{array}$ \\
\hline NUMBER OF REFERENCES & NUMBER OF FIGURES & NUMBER OF TABLES \\
\hline 0 & 0 & 0 \\
\hline
\end{tabular}

(C) The author(s) 2023. This publication is an open access article. 
Vusi Gumede (South Africa), Mduduzi Biyase (South Africa)

\title{
Educational reforms and curriculum transformation in post-apartheid South Africa
}

\begin{abstract}
Educational reforms and curriculum transformation have been a priority in South Africa since the establishment of the Government of National Unity in 1994. Education is critical in redressing the injustices of apartheid colonialism which created an inequitable and fragmented education system. Factors such as school access, governance, curriculum, teacher deployment and financial resources have also gone through the education policy mill. While relatively impressive progress is observed regarding legislative interventions, policy development, curriculum reform and the implementation of new ways of delivering education, many challenges remain. Key among the challenges relates to the quality of education, twenty two years since the dawn of democracy. To contribute to the debate on educational reforms and pertaining to the quality of education, the paper discusses the various curriculum reforms of South Africa's education sector and provides a brief evaluation of the trends in policies affecting equity and quality in the South African education environment. The paper finds that the quality of education is critical for many reasons.
\end{abstract}

Keywords: National Income Dynamics Study, Pooled OLS, fixed effect and random effect.

JEL Classification: C31, I21, J31.

\section{Introduction}

There have been some commendable changes in the education landscape in South Africa since 1994. However, as Gumede (2013) argues, there remain policy questions that are yet to be addressed. The recent policy interventions in the form of the 2013 White Paper for Post-School Education and the various curricula reforms are part of an effort to address the policy issues that need attention. There are new challenges, particularly those associated with the Rhodes Must Fall and Fees Must Fall movement, at least the higher education level. One of policy issues that has not been sufficiently addressed has to do with the quality of education in post-apartheid South Africa. As Msila (2007) argues, education was used as a political tool to divide society and create a certain form of identity among learners during apartheid dispensation. Tabata (1997) makes a point that Africans were subjected to what was known as 'Native Education' under the Bantu Education Act of 1959 during the apartheid system. Therefore, the post-apartheid educational reforms and curriculum transformation are/were a direct response to apartheid curricula that were described as authoritydriven and elitist (Jansen and Taylor, 2003, p. 37).

The Constitution of the Republic of South Africa (Act 106 of 1996) provides the basis for educational reforms and curriculum transformation in South Africa's education system. According to Burke (1995, p. 3), the beginning of the process of curriculum change existed in the manifestation of concerns, needs and dissatisfactions of curriculum practices of

(C) Vusi Gumede, Mduduzi Biyase, 2016.

Vusi Gumede, Ph.D., Professor, Head of Thabo Mbeki African Leadership Institute, University of South Africa, South Africa.

Mduduzi Biyase, Ph.D. Candidate, Lecturer in Economics and Econometrics, University of Johannesburg, South Africa. the time, creating a need for variation. Malan (2000) argues that education is aimed at creating teaching and learning environments that would bring about desired changes in learners, whether to be more knowledgeable, better skilled or to influence their attitudes and values positively. The very essence of teaching and learning is to determine to what extent learners have acquired the intended competences (Malan, 2000, p. 01). Jansen and Taylor (2003) argue that, in the main, education in post-apartheid South Africa is designed to equitably produce informed, productive and progressive citizens who value and practice the principles enshrined in the Constitution of the Republic of South Africa. As Gumede (2013, p. 77) concludes, "attention should be paid to improving not only access to education but also to the quality of education. This is particularly important with regard to teacher training, the curriculum, access to information for parents and learners..." This paper deals with quality of education.

The next Section briefly discusses educational reforms and curriculum transformation processes since 1994. It looks at the specific changes in curriculum, in policy terms. It is, then, followed by a Section dealing with effects of educational reforms. It examines the quality of education in South Africa and its effects using the National Income Dynamics Study - The National Income Dynamics Study (NIDS) is a longitudinal survey and/or panel study whose data are collected at 2-year intervals since 2008. The paper, then, concludes.

\section{Educational reforms and curriculum transfor- mation processes since 1994}

The main reforms pursued since were institutional. For instance, 19 departments of education had to be rationalized into a single national department of 
education and nine provincial departments of education. There were also numerous policy reforms, mainly to ensure access to education by those who were previously excluded. The focus of this paper is on curricula, as far as quality of education is concerned. Perhaps, the ideal starting point in discussing curricula changes in post-apartheid South Africa relates to the introduction of Curriculum 2005, also known as the 'Outcomes Based Education (OBE) curriculum'. Harden, Crosby and Davis (1999, p. 8) suggest that, in outcome-based education approaches the end product defines process. Therefore, an outcome-based education program can be summed up as results-oriented thinking, which is the opposite of input-based education where the emphasis is on the educational process (Davis, 2003).

Many countries introduced OBE in the 1980s and 1990s for different reasons, especially at a time where there was increasing call for accountability (Ramoroka, 2007, p. 46). According to Davis (2003), South Africa developed its own OBE model. South Africa's Ministry of Education launched the OBE system in the year 1997. The OBE was said to be concentrated on the learner and the outcomes the learner should be able to achieve. In the OBE model, every learner was respected as an individual, and no learner, regardless of race, ethnicity and cultural background, was deemed better than the other. Everyone was accommodated in their learning environments (Ramoroka, 2007, p. 47). Due to the challenges that were identified as constraining OBE, the National Curriculum Statement 2002 (NCS) was introduced. Contrary to the OBE curricula, the NCS curricula required that all learners in grades 10,11 and 12 do a minimum of 7 subjects, as opposed to the 6 subjects. In the NCS curricula, learners are expected to learn a minimum of two South African languages. In addition to the two languages, learners are expected to make a compulsory choice between Mathematics and Mathematical Literacy, and they are expected to study Life Orientation.

In year 2000, a Ministerial Committee was appointed to review the progress and effectiveness of the curriculum (Department of Education, 2002). According to the Department of Education (2004), the brief of the review was the structure and design of the curriculum, teacher orientation, training and development, learning support materials, provincial support to teachers in schools and implementation time frames. The Ministerial Committee recommended that the curriculum be streamlined, and that it should be modified to make it more accessible to the educators - amendments were, then, effected in the National Curriculum Statement (NCS) 2002, culminating to the Revised National Curriculum
Statement. Bynard (2011, p. 61) had opined that the NCS2002 placed a heavy burden on the educators who were to become the ultimate drivers of educational transformation in schools. Badgelat (2012, p. 10) supports Bynard that "not only were teachers inadequately trained, but there was also a shortage of resources and lack of support from government". Maphalala (2006, p. 66) also argues that a lack of preparation among educators was also a problem in adequately implementing the NCS curricula.

From the Revised National Curriculum Statement, the Curriculum Assessment Policy Statement (CAPS) was introduced in the year 2012. Pinnock (2011) argues that CAPS is not a new curriculum; it is rather an amendment to NCS. As Du Plessis (2013) puts it, much of the debate around CAPS is about whether or not it is an amendment, repackaging or recurriculation. Indeed, NCS and CAPS have similar rationales when it comes to situating the curriculum within the aims of the South African constitution and both NCS and CAPS contain a similar list of values (including social justice, human rights, environmental awareness and respect for people from diverse cultural, religious and ethnic backgrounds).

\section{Effects of educational reforms since 1994}

There has been a good deal of work that investigates the impact of educational reforms on earnings in particular, since 1994, in South Africa. These studies include the works of Heckman et al. (1995), Case and Yogo (1999); Keswell and Poswell (2004), Aromolan (2006, 2004) and several other scholars.

The return to education literature has suggested several measures of quality of schooling or education. These measures can be grouped into two broad categories: output measures and input measures. The most common proxies for input measures are expenditure per pupil, the pupil-teacher ratio, teacher's experience, education levels and teacher-test scores. Output measures are usually proxies by test scores of individual students - direct outcomes of education. Several authors have used the input measure such as pupil-teacher ratios (see Card and Krueger (1992), Case and Yogo (1999), Heckman et al. (1995), Dearden et al. (2002)). While others have used cognitive ability (see Castex et al. (2011), Blau et al. (2005), Aslam et al (2008), Lee et al (2013) and Kavuma (2015)), some authors in this field such as Branson and Leibbrandt (2013b) have used both input and output measures.

A recent study by Branson and Leibbrandt (2013) used a merged data (i.e., National Income Dynamics Study, the School Register of Needs Survey 2000 and school level matriculation results from 2000) to investigate the impact of quality of education on 
earnings in South Africa. Using matric exemption scores and the pupil-teacher ratio of the respondents' closest school during childhood as proxies for education quality, they found that a 10 percentage point increase in matric exemption score leads to $8 \%$ rise in earnings, while a decrease in the pupil-teacher ratio by one learner leads to a $1 \%$ increase in earnings.

Case and Yogo (1999) investigated the return to education in South Africa using South African Census data and two national surveys of school quality. Quality of education is measured pupil-teacher ratio (i.e. input measure). They regress return to education on various measures of magisterial district school quality and other characteristics of the magisterial district. Their results suggest that the quality of schools does matter. A decrease in the pupilteacher ratio of 5 students was found to be associated with $1 \%$ increase in the returns to education.

In case of other countries, Aslam et al (2008), for instance, studied the effect of quality of education on earnings in Pakistan based on purpose-designed survey data of more than 1000 households in 2007. They use cognitive ability as a measure for quality of education. They found that "much of the direct effect of cognitive skills disappears after conditioning on schooling, i.e., skills do not have an independent effect on earnings over and above the effect via schooling". Another country where similar estimations have been done is United States (U.S.). Blau et al. (2004), in their analysis of the impact of quality of education on earnings in the U.S., showed that performance on cognitive tests is an important determinant in U.S. wage inequality.

\section{Data and analysis}

The paper employed panel data framework to explore the effects of quality of education on earnings in South Africa. The panel structure of the dataset permits us to use various panel data models: pooled OLS, fixed and random effects estimation. The Pooled OLS is similar to the method of standard ordinary least squares. The difference is that pooled OLS estimation widens the database by pooling together cross sectional and time series observations of the sample to get more reliable estimates of the parameters (Pulok, 2012). In other words, it uses more information than standard OLS.

However, the Pooled OLS estimation is not always appropriate for use with panel data for two reasons. Firstly the errors are likely to be correlated within panels. Secondly, the unmeasured heterogeneity that causes this correlation may bias parameter estimates (Greene, 2000). Researchers address these problems by employing the random effects model and the fixed effects. Researchers use the fixed effect estimation in order to account for unobservable effects specific to individual or households in panel data. This model assumes that the unobservable specific effects do not vary over time and that they are correlated with other explanatory variables. In the random effects model, unobservable specific effects are assumed to be uncorrelated to independent variables.

We use the Hausman specification test to identify the most appropriate estimator (i.e., between fixed effect and random effect) for our analysis. The null hypothesis underlying this test is that the fixed effect and random effect estimators do not differ substantially. If the null hypothesis is rejected, random effect is not appropriate and it may be better to use fixed effect. The Hausman specification test supports random effects estimation for the regressions. This suggests that random effects estimation will provide more efficient estimators without sacrificing consistency. We express the relationship between earnings and quality of education by the following representation of the panel data models - random effect model:

$\ln _{i t}=\alpha_{0}+\alpha_{1}$ Qeducation $_{i t}+\alpha_{2} \ln X_{i t}+\delta_{i}+\pi_{i t}$,

where $\ln E_{i t}$ represents earnings of individual $i$ at time $t$. The error term $\pi_{i t}$ includes both preference shocks and measurement error and is distributed identically and independently. $X_{i t}$ are individual characteristics including the age of the household head, education of the household head family size, etc.

Estimating the effect of education on earnings raises some concerns: endogeneity. Following many authors (see Card, 2001; Heckman et al., 2006; Kerr and Quinn, 2010; Leyaro et al., 2010; Rankin Sandefur and Teal, 2010) in this field. we complement more standard panel estimation techniques (random effects) with the two-stage least squares (2SLS) in order to deal with endogeneity bias.

\section{Results}

Before executing econometric analysis, we take an initial look at average earnings by race and geo-type which allows us to highlight some, but interesting stylized facts. 


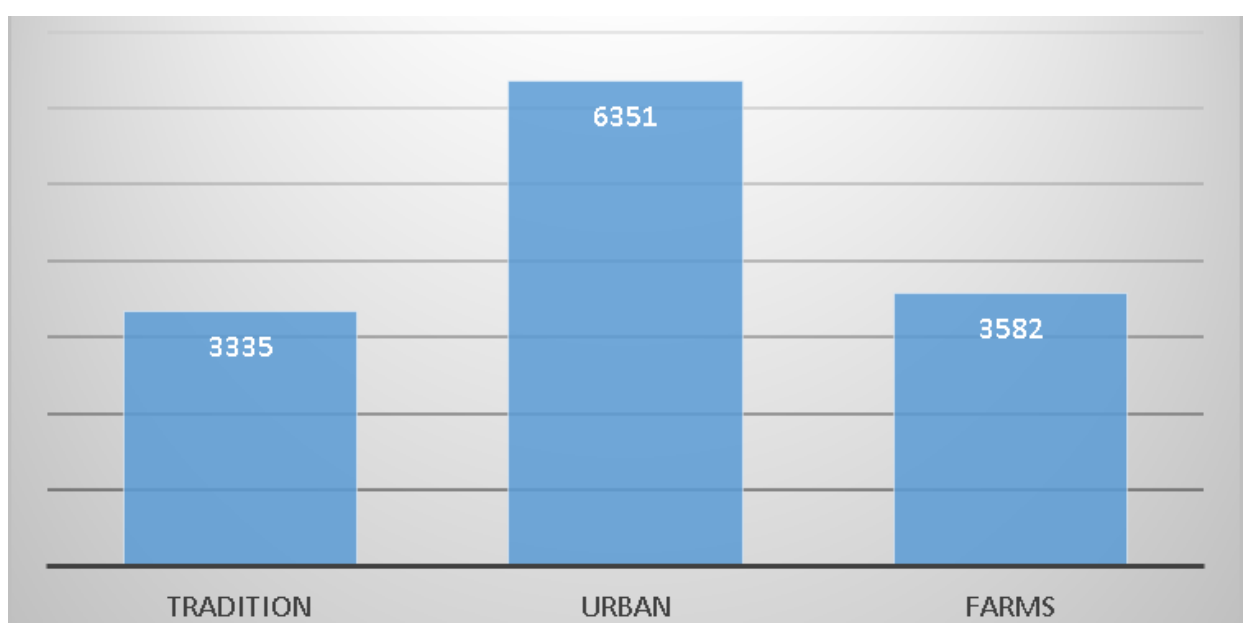

Fig. 1. Average earnings by geo-type in South Africa (2008-2012)

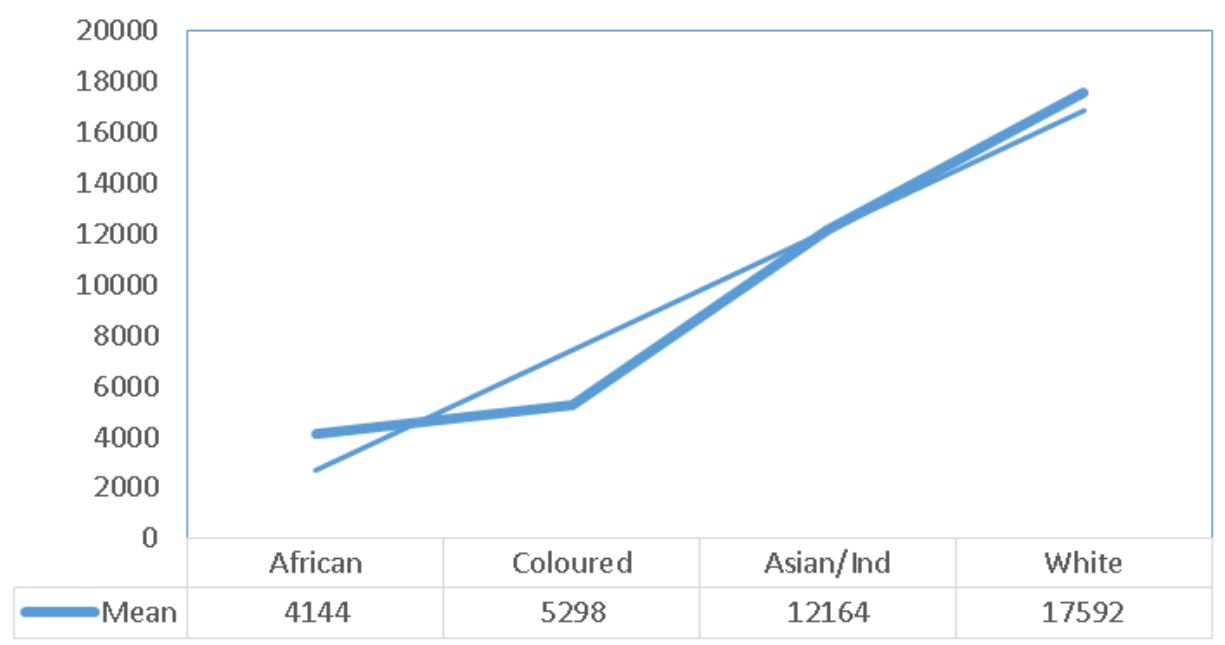

Fig. 2. Average wage by race in South Africa (2008-2012)

Figure 1 compares earnings across urban-rural areas, with urban areas having substantially higher earnings than rural areas. More specifically, average earnings are considerably higher in urban areas, at R6351 compared to R3335 and R3582, in traditional and farm areas. In South Africa, such variations in earnings across urban-rural areas account for a large part of the variation in provincial earnings. Where provinces whose populations are concentrated in rural areas (e.g., Kwazulu
Natal and Limpopo Province) have much lower earnings than their counter part. Figure 2 shows a breakdown of earnings by race. As expected, average earnings of Blacks are typically less than their white counterparts, Indians, and coloured group. More precisely, average earnings of white (R17592) and Indian/Asian (R12164) population are markedly higher than the average monthly average earnings of their coloured (R5298) and black African (R4144) counterparts.

Table 1. Random effects and 2SLS estimates of the effect of quality of education on earnings in SA

\begin{tabular}{|c|c|c|c|c|}
\hline & Random effects & Standard errors & Two stage least square & Standard errors \\
\hline Quality of education & $0.6360305^{\star \star \star}$ & $(0.0259131)$ & $0.7882978^{\star \star \star}$ & $(0.023979)$ \\
\hline Age & -0.0003615 & $(0.0009445)$ & 0.0010079 & $(0.000849)$ \\
\hline Hhsize & $0.0532638^{* \star *}$ & $(0.0051591)$ & $0.0451484^{* * *}$ & $(0.004113)$ \\
\hline Married & $0.3572548^{* \star *}$ & $(0.0260524)$ & $0.4014152^{\star \star *}$ & $(0.024364)$ \\
\hline Gender female & $-0.1527743^{\star \star \star}$ & $(0.0257938)$ & $-0.1327184^{\star \star \star}$ & $(0.023032)$ \\
\hline Coloured & $0.1758612^{* \star *}$ & $(0.0433271)$ & $0.1668093^{\star * *}$ & $(0.040095)$ \\
\hline Indians & $0.5122276^{\star \star \star}$ & $(0.157138)$ & $0.4222781^{* \star *}$ & $(0.126643)$ \\
\hline Whites & $1.02798^{\star \star *}$ & $(0.060356)$ & $0.9528433^{\star \star \star}$ & $(0.052959)$ \\
\hline Urban & $0.1590205^{* \star *}$ & $(0.0396837)$ & $0.1760105^{\star * *}$ & $(0.038465)$ \\
\hline Farms & $-0.1937742^{* * *}$ & $(0.0328345)$ & $0.168788^{\star \star \star}$ & $(0.033631)$ \\
\hline
\end{tabular}


Table 1 (cont.). Random effects and 2SLS estimates of the effect of quality of education on earnings in SA

\begin{tabular}{|l|c|c|c|c|}
\hline & Random effects & Standard errors & Two stage least square & Standard errors \\
\hline Eastern Cape & -0.0100805 & $(0.0669521)$ & -0.0118249 & $(0.059278)$ \\
\hline Northern Cape & $-0.2889932^{* \star \star}$ & $(0.0648364)$ & $-0.2854763^{\star \star \star}$ & $(0.055431)$ \\
\hline Free State & -0.0383868 & $(0.0694083)$ & $-0.0319402^{\star \star *}$ & $(0.060744)$ \\
\hline KwaZulu-Natal & $-0.1893292^{* \star *}$ & $(0.0744628)$ & $-0.1672994^{\star \star *}$ & $(0.060846)$ \\
\hline North West & $-0.1093459^{\star}$ & $(0.056183)$ & $-0.0935632^{\star}$ & $(0.047915)$ \\
\hline Gauteng & $0.2065311^{\star \star \star}$ & $(0.0677939)$ & $0.2060117^{\star \star \star}$ & $(0.058864)$ \\
\hline Mpumalanga & $0.1700879^{\star \star \star}$ & $(0.0611294)$ & $0.1374076^{* \star \star}$ & $(0.053575)$ \\
\hline Limpopo & $0.2204411^{\star \star \star}$ & $(0.0639706)$ & $0.2238369^{\star \star \star}$ & $(0.056075)$ \\
\hline
\end{tabular}

Notes: Standard errors in parentheses. * significant at $10 \%$;* significant at $5 \%$; *** significant at $1 \%$.

The estimated results for both the random effect and the two-stage least squares models are presented in Table 1. In column (2), the results of the random effect estimation are reported. These results based on the Random effect model suggest that the quality of education does matter - positive and significantly on earnings. Specifically, estimate suggests that an improvement in the quality of education increases the earnings by $63 \%$. Consistent with Arshaf and Ashraf (1993), Khan and Irfan (1985), we found that the coefficient for the control variables such as gender (female) and geo-type (farm areas) is negative and significant which reinforces the perception that females earn less than males, and that earnings are lower in farm or rural areas than urban areas. The results for the other control variables (i.e., marital status) are as expected - positive and, statistically, significantly different from zero.

As noted in the previous Section, a legitimate concern raised by many studies in this field is that the quality of education might be endogenously related to earnings. In order to account for endogeneity and to reduce the bias associated with it, the model is estimated by using two-stage least squares models. The results of the two-stage least squares are reported in column (4). There are, at least, two crucial features governing the selection of an instrument for education: the instrument must be correlated with education and its effect on earnings must operate solely through its effect on education and should not be directly affected by earnings. The instrument that is used here is the lagged value of education, which has been used in the previous studies.

After accounting for endogeneity, we find that the quality of education retains its positive and significant effect on earnings. Although in both specifications, the coefficients of this variable are significant at the $1 \%$ level (confirming that quality of education matters for earnings), the estimates of the two stage least square (78\%) are larger than the baseline estimates $(63 \%)$. Such difference confirms that the two stage least square estimator provides less prone to mis-specification than random or fixed effect estimator (Belzil, 2007; Keane, 2010). To summarize, the results across all models indicate a statistically significant impact of education on wages.

\section{Conclusion}

Although the OBE was reported to have not worked in South Africa, according to Olivier (2009), OBE had the potential to be a good education curriculum, because it was more concerned with producing critically thinking and creative learners. Many have argued that, also, the NCS2002 did not work, hence, the Revised National Curriculum Statement and the CAPS. Arguably, the biggest challenge in the South Africa's overall education system is that learners and students are given overly long course-outlines to read. In most cases, the quality of the course will be assured after the peer-review process. But one would agree that, in the context of socio-economic transformation, the reforms of the education system post 1994 are of necessity and have worked relatively well in improving the governance of the educational system, access to education and so forth. This is visible in the progress made so far towards more inclusive, equitable and efficient policy-making processes between government and social partners, and among the national and provincial levels, as facilitated by various pertinent policies and legislation (Gumede, 2008). However, the quality of education remains a challenge. As this paper demonstrates, the quality of education is critical for many reasons.

\section{References}

1. Aakvik, A., Salvanes, K., Vaage, K. (2003). Measuring heterogeneity in the returns to education in Norway using educational reforms. IZA Discussion Paper 815, Bonn.

2. Ali-Dinar, A.B. (1994). ANC Education Policy. Available at: http://www.africa.upenn.edu/Govern_ Political/ANC_Education.html. (Accessed: : December 2014). 
3. Angrist, J.D., Kreuger, A.B. (1991). Does compulsory school attendance affect schooling and earnings? The Quarterly Journal of Economics, 106(4), pp. 979-1014.

4. Ann Case and MotohiroYogo. (1999). Does school quality matter? Returns to education and the characteristics of schools in South Africa. NBER Working Paper 7399, National Bureau of Economic Research.

5. Aromolaran, A.B. (2004). Wage returns to schooling in Nigeria, African Development Review, 16(3), pp. $433-455$.

6. Aromolaran, A.B. (2006). Estimates of mincerian returns to schooling in Nigeria, Oxford Development Studies, 34(2), pp. 265-292.

7. Ashenfelter, O., Rouse, C. (1998). Income, schooling, and ability: Evidence from a new sample of identical twins, The Quarterly Journal of Economics, 113(1), pp. 253-284.

8. Ashenfelter, O., Krueger, A. (1994). Estimates of the economic return to schooling for a New Sample of Twins, American Economic Review, 84(5), pp. 1157-1173.

9. Belzil, C. (2007). The return to schooling in structural dynamic models: A Survey, European Economic Review, 51(5), pp. 1059-1105.

10. Belzil, C. Hansen, J. (2002). Unobserved ability and the return to schooling, Econometrica, 70(5), pp. $2075-2091$.

11. Bennel, P. (1996). Rates of return to education: Does the conventional pattern prevail in Sub-Saharan Africa? World Development, 24(1), pp. 183-199.

12. Bonjour, D., Lynn, F., Cherkas, J.E., Haskel, D., Hawkes, D., Spector, T. (2003). Returns to Education: Evidence from UK Twins, American Economic Review, 93(5), pp. 1799-1812.

13. Branson, N., Ardington, C., Lam, D., Leibbrandt, M. (2013). Changes in education, employment and earnings in South Africa - A cohort analysis. SALDRU Working Paper 105, University of Cape Town.

14. Burger, R. (2011). Estimating the shape of the South African schooling-earnings profile. Doctoral dissertation. Oriel College, Oxford University.

15. Burger, R., Jafta, R. (2006). Returns to Race: Labor market discrimination in Post-Apartheid South Africa. University of Stellenbosch Working Paper.

16. Burger, C., Van de Berg, S. (2011). Modelling cognitive skills, ability and school quality to explain labor market earnings differentials. Stellenbosch Economic Working Papers: 08/11.

17. Burke, J. (Ed.). (1995). Outcomes, Learning and the Curriculum: implications for NVQs, GNVQs and other qualifications. London \& Washington: The Falmer Press.

18. Card, D. (1999). The causal effect of education on earnings. Handbook of Labor Economics, Edited by Ashenfelter, O. and Card D. 3 (1), pp. 1801-1863.

19. Carneiro, P., Heckman, J. (2002). The evidence on credit constraints in postsecondary schooling, Economic Journal, 112(482), pp. 705-734.

20. Christie, P. (1995). Global trends in local contexts: a South African perspective on competency debates, unpublished paper. University of the Witwatersrand: Johannesburg.

21. Davis, H.M. (2003). Outcome-Based Education. Available on http://www.jfn.ac.lk/OBESCL/MOHE/OBEArticles/Academic-documents-articles/6.OBE-Davis.pdf. Accessed: : 10 February 2016.

22. De Gregorio, J., Lee, W. (2002). Education and income inequality: new evidence from cross-country data, Review of Income and Wealth, 48(3), pp. 395-416.

23. Department of Basic Education. (2009). Report of the task team for the review of the implementation of the National Curriculum Statement. Pretoria: Government Printer.

24. Department of Education. (2009). Report of the Task Team for the Review of the Implementation of the National Curriculum Statement. Pretoria: Department of Education.

25. Department of Education. (2003). Revised National Curriculum Statement Grades 10-12: Overview. Pretoria: Department of Education.

26. Department of Education. (2002). Overview: Revised National Curriculum Statement Grades R-9 (Schools). Pretoria: Department of Education.

27. Department of Higher Education and Training. (2013). White Paper on Post-School Education. Pretoria: Higher Education and Training.

28. Department of Public Service and Administration. (1995). White Paper on the Transformation of the Public Service. Pretoria: Department of Public Service and Administration.

29. Dearden, L., Ferri, J. and Meghir, C. (2002). The effect of school quality on educational attainment and wages, Review of Economics and Statistics, 84(1), pp. 1-20.

30. De la Fuente, A. (2003). Human capital in a global and knowledge-based economy. Assessment at the EU Country Level. Report for the European Commission. DG for Employment and Social Affairs.

31. Duflo, E. (2000). Schooling and labor market consequences of school construction in Indonesia: Evidence from an Unusual Policy Experiment, The American Economic Review, 91(4), pp. 795-813.

32. Du Plessis, E. (2013). Introduction to CAPS: Curriculum and Assessment Policy Statement. Pretoria: UNISA.

33. Fang, H., Eggleston, K.N., Rizzo, J., Rozelle, S., Zeckhauser, J. (2012). The Returns to education in China: Evidence from the 1986 Compulsory Education Law. NBER Working Paper 18189.

34. Finn, A., Leibbrandt, M. (2013). The dynamics of poverty in the first three waves of NIDS. Cape Town: SALDRU, University of Cape Town. SALDRU Working Paper No. 119/NIDS Discussion Paper 2013/1. 
35. García-Mainar, I., Monteuenga-Gómez, V.M. (2005). Education returns of wage earners and self-employed workers: Portugal vs. Spain, Economics of Education Review, 24(2), pp. 161-170.

36. Gumede, V. (2008). Public Policy Making in a Post-Apartheid South Africa - A Preliminary Perspective, Africanus: Journal of Development Studies, 38(2), pp. 7-23.

37. Gumede, V. (2013). Public Sector Reforms and Policy-making: A Case of Education in an Emerging Developmental South Africa, in Kanjee, A., Nkomo, M., and Sayed,Y. (eds.), The Search for Quality Education in Postapartheid South Africa. Pretoria: HSRC Press.

38. Harmon, C., Oosterbeek, H., Walker, I. (2003). The Returns to education - A Review of evidence, issues and deficiencies in the literature, Journal of Economic Surveys, 17(2), pp. 115-156.

39. Halligan, J. (2007). Reintegrating government in third government reform of Australia and New Zealand, Social Policy and Administration, 22(2), pp. 217-238.

40. Heckman, J., Stirxud, J., Urzua, F. (2006). The effect of cognitive and non-cognitive factors in behavioral and labor outcomes, Journal of Labor Economics, 24(3), pp. 411-482.

41. Harmon, C. Walker, I., Westergaard-Nielsen, N. (2001). Education and earnings in Europe. A Cross Country Analysis of the Returns to Education. Cheltenham, UK and Northampton, MA, USA: Edward Elgar.

42. Harden, R.M., Crosby, J.R. and Davis, M.H. (1999). An introduction to outcome-based education, Med Teacher, 21(1), pp. 7-14.

43. Jansen, J.D. (1999). Curriculum Reform in South Africa: A Critical Analysis of Outcomes-Based Education, Journal of Curriculum Studies, 27, pp. 245-261.

44. Kavuma Oliver Morrissey, and Richard Upward (2015). Private returns to education for wage-employees and the self-employed in Uganda. WIDER Working Paper 2015/021.

45. Keane, M. (2010). Structural vs. atheoretic approaches to econometric, Journal of Econometrics, 156(1), pp. 3-20.

46. Kerr, A.S., Quinn, S. (2010). Returns to education in Tanzania: Exploiting a natural experiment. Paper presented in the Centre for the Study of African Economies Conference on Economic Development in Africa, 21-23 March 2010, St Catherine's College, Oxford, UK.

47. Kimenyi, M., Mwabu, G., Manda, K. (2006). Human capital externalities and private returns to education in Kenya, Eastern Economic Journal, 32(3), pp. 493-513.

48. Keswell, M., Poswell, L. (2004). Returns to education in South Africa: a retrospective sensitivity of the available evidence, South African Journal of Economics, 72(4), pp. 834-860.

49. Lam, D., Ardington, C., Leibbrandt, M. (2011). Schooling as a lottery: Racial differences in school advancement in Urban South Africa, Journal of Development Economics, 95(2), pp. 121-136.

50. Martins P., Pereira, T. (2004). Does education reduce wage inequality? Quantile regression evidence from 16 countries, Labor Economics, 11 pp. 355-371.

51. Malan, S.P.T. (2000). The 'new paradigm' of outcomes-based education in perspective.Tydskrifvir Gesinsekologieen Verbruikerswetenskappe, Vol. 28.

52. Mahomed, N. (1996). Competence: past debates and future problems. EPU Working Paper No. 10 (Durban, University of Natal/Durban).

53. Maphalala, M.C. (2006). Educators' Experiences in Implementing the Revised National Curriculum Statement in the Get Band. Submitted to the Faculty of Education in fulfilment of the requirements for the degree Of Doctor of Education in the Department of Curriculum \& Instructional Studies at the University of Zululand.

54. Mason, M. (1999). Outcomes-based Education in South African Curricular Reform: a response to Jonathan Jansen, Cambridge Journal of Education, 29(1), pp. 137-143.

55. Mincer, J. (1974). Schooling, experience and earnings. National Bureau of Economics, New York: Columbia University Press.

56. Mocan, L. (2014). The impact of education on wages: Analysis of an Education Reform in Turkey. Wharton School of Business. Working Paper 109, April 2014.

57. Moll, G. (1998). Primary schooling, cognitive skills, and wage in South Africa, Economica, 65, pp. $263-284$.

58. Moleke, P. (2006). Finding work: Employment experiences for South African graduates. Cape Town: HSRC Press.

59. Msila, V. (2007). From Apartheid Education to the Revised National Curriculum Statement: Pedagogy for Identity Formation and Nation Building in South Africa, Nordic Journal of African Studies, 16(2), pp. 146-160.

60. Mwabu, G., Schultz, T. (1996). Education returns across quantiles of the wage functions: alternative explanations for returns to education by race in South Africa, The American Economic Review, 86(2), pp. 335-339.

61. Ntuli, M. (2007). Exploring gender wage discrimination in South Africa, 1995-2004: A Quantile Regression Approach. IPC Working Paper Series: 56.

62. Okuwa, O.B. (2004). Private returns to higher education in Nigeria. AERC Research paper No. 139, Nairobi Kenya.

63. Oreopoulos, P. (2006). Estimating average and local treatment effects of education when compulsory schooling laws really matter, The American Economic Review, 96(1), pp. 152-175.

64. Plug, E. (2001). Season of birth, schooling and earnings, Journal of Economic Psychology, 22, pp. 641-660.

65. Psacharopoulos, G. (1994). Returns to investment in education: A global update. World Development 22(9), pp. 1325-1343. 
66. Psacharopoulos, G. Patrinos, H. (2004n). Returns to investment in education: A further update, Education Economics, 12(2), pp. 111-134.

67. Pinnock, A.J.E. (2011). A practical guide to implementing CAPS: A toolkit for teachers, schools managers and education officials to use to assist in managing the implementation of a new curriculum. NAPTOSA.

68. Policy Coordination and Advisory Services in the Presidency. (2008). Towards a fifteen year review, synthesis report on the implementation of government programmes. Accessed: : August 2012. Available at: http://www. thepresidency.gov.za/main.asp?include=docs/15year/main.html.

69. Pottinger, B. (2008). The Mbeki Legacy. Zebra Press: Cape Town.

70. Ramoroka, N.J. 2007). Educators Understanding of the Premises Underpinning Out-Come-Based Education and its Impact on their Classroom Assessment. Available at: http://www.jfn.ac.lk/OBESCL/MOHE/OBEArticles/Books-chapters-n-Reports/1.Assessment-n-QA.pdf. Accessed: : 10 February 2016.

71. Rankin, N., Sandefur, J., Teal, F. (2010). Learning and earnings in Africa: where are the returns to education high? Working Paper. Oxford: Centre for the study of African Economies.

72. Salehi-Isfahani, D., Tunali, I., Assaad, R. (2009). A comparative study of returns to education of urban men in Egypt, Iran, and Turkey, Middle East Development Journal, 1(2), pp. 145-187.

73. Schultz, T. (1999). Health and schooling investments in Africa, Journal of Economic Perspectives, 13(3), pp. 67-88.

74. Statistics South Africa. (2014). Poverty trends in South Africa: an examination of absolute poverty between 2006 and 2011. Statistics South Africa. Report No. 03-10-06.

75. Statistics South Africa. (2015). Methodological report on rebasing of national poverty lines and development on pilot provincial poverty lines: Technical Report. Pretoria: Statistics South Africa.

76. Tabata, I.B. (1979). Education for Barbarism. Available at: http://www.sahistory.org.za/archive/educationbarbarism-ib-tabata-october-1979 (Accessed: : March 12, 2014).

77. Taylor, N. and Jasnen, J. (2003). Educational Change in South Africa 1994-2003: Case Studies in Large-Scale Education Reform, Country Studies Education Reform and Management Publication Series, 2(1), pp. 1-47.

78. The Constitution of the Republic of South Africa. (1996).

79. Trostel, P., Walker, I., Woolley, P. (2001). Estimates of the economic return to schooling for 28 countries, Labor Economics, 9(1), pp. 1-16. 